\title{
Induction of Apoptosis and Cell Cycle Arrest in Human Colorectal Carcinoma by Litchi Seed Extract
}

\author{
Chih-Ping Hsu, ${ }^{1}$ Chih-Cheng Lin, ${ }^{2}$ Chiu-Chen Huang, ${ }^{3}$ Yi-Hsien Lin, ${ }^{2}$ Jyh-Ching Chou, ${ }^{4}$ \\ Yu-Ting Tsia, ${ }^{1}$ Jhih-Rou Su, ${ }^{1}$ and Yuan-Chiang Chung, 6 \\ ${ }^{1}$ Department of Medical Laboratory Science and Biotechnology, Yuanpei University, Hsinchu 30015, Taiwan \\ ${ }^{2}$ Department of Biotechnology, Yuanpei University, Hsinchu 30015, Taiwan \\ ${ }^{3}$ Department of Anesthesiology, China Medical University Hospital, Taichung 40447, Taiwan \\ ${ }^{4}$ Department of Natural Resources and Environmental Studies, National Dong Hwa University, Hualien 97401, Taiwan \\ ${ }^{5}$ Department of Surgery, Cheng-Ching Hospital, Chung-Kang Branch, No. 118 SEC.3 Chung Kang Road, Taichung City 407, Taiwan \\ ${ }^{6}$ Department of Surgery, National Taiwan University Hospital, Taipei 10048, Taiwan
}

Correspondence should be addressed to Yuan-Chiang Chung, 11722@ccgh.com.tw

Received 13 May 2012; Accepted 29 July 2012

Academic Editor: Rudi Beyaert

Copyright (C) 2012 Chih-Ping Hsu et al. This is an open access article distributed under the Creative Commons Attribution License, which permits unrestricted use, distribution, and reproduction in any medium, provided the original work is properly cited.

\begin{abstract}
The Litchi (Litchi chinensis) fruit products possess rich amounts of flavanoids and proanthocyanidins. Its pericarp has been shown to inhibit breast and liver cancer cell growth. However, the anticolorectal cancer effect of Litchi seed extract has not yet been reported. In this study, the effects of polyphenol-rich Litchi seed ethanol extract (LCSP) on the proliferation, cell cycle, and apoptosis of two colorectal cancer cell lines Colo320DM and SW480 were examined. The results demonstrated that LCSP significantly induced apoptotic cell death in a dose-dependent manner and arrested cell cycle in G2/M in colorectal carcinoma cells. LCSP also suppressed cyclins and elevated the Bax:Bcl-2 ratio and caspase 3 activity. This study provides in vitro evidence that LCSP serves as a potential chemopreventive agent for colorectal cancer.
\end{abstract}

\section{Introduction}

Colorectal cancer (CRC) has become the most common type of cancer in Taiwan since the Taiwanese diet has become increasingly westernized during recent decades [1, 2]. Although Taiwan has a strong current and historical emphasis on traditional Chinese medicine, limited research has been directed towards evaluating the potential of natural plants or herbs as novel bioactive compounds against colorectal cancer. Litchi (Litchi chinensis, Sapindaceae) is a tropical fruit tree that originates from southern China and is cultivated in semitropical areas worldwide for its delicious taste of the fruit [3]. In China, litchi seeds are used to release stagnant humor and remove chilling, and the seeds serve as an analgesic agent that can relieve the symptoms of coughing, gastralgia, neuralgia, and testicular swelling. Pharmacological studies have revealed that Litchi seeds exert antihyperlipidemic, hypoglycemic, and antitumor effects [4-6]. In India, the seeds are powdered as a herbal medicine owing to their astringency, and after oral intake they have the reputation of relieving neuralgic pains [7]. Recent studies have revealed that Litchi pericarp is composed of significant amounts of flavonoids and anthocyanins, including procyanidin B2, B4, epicatechin, cyanidin-3-rutinoside, cyanidin-3-glucoside, quercetin-3-retinoside, quercetin-3glucoside, and so forth [7]. These components carry high free radical scavenging properties and could be used as antiinflammation, anti-oxidation, or anticancer agents $[8,9]$. Wang and coworkers showed that Litchi pericarp ethanol extract inhibited the in vitro and in vivo growth of mouse hepatocellular carcinoma and both estrogen-dependent and independent human breast carcinoma cells $[10,11]$. However, the Litchi pericarp is the edible part of the Litchi fruit, and overdosing may lead to some consumers' uncomfortable "heating" [12]. In recent reports, polyphenol compounds from Litchi seeds were identified and composed of a variety of proanthocyanidins and flavonoid glycoside [13, 14]. Some of these compounds appear to exhibit antineoplasm activities 
in lung cancer, cervical cancer and hepatocellular carcinoma cells [15]. However, there is no report to demonstrate the effect and mechanism of Litchi seed extract on anticolorectal carcinoma. Here, we investigated the effect of Litchi seed ethanol extract (LCSP) on colon cancer cell lines Colo320DM and SW480 and attempted to evaluate the potential usage of LCSP for the chemoprevention and treatment of CRC.

\section{Materials and Methods}

2.1. Chemicals. RPMI, fetal bovine serum, L-glutamine, trypsin, and antibiotics were purchased from Gibco Ltd. (Paisley, UK). Proteinase inhibitor cocktail, sodium orthovanadate, sodium fluoride, sodium pyrophosphate, Triton X-100, ammonia persulfate, $N, N, N^{\prime}, N^{\prime}$-tetramethylethylenediamine (TEMED), and Tween 20 were obtained from Sigma (St. Louis, MO, USA). Bicinchoninic acid (BCA) protein assay reagent was purchased from Pierce (Rockford, IL, USA). Acrylamide was obtained from Bio-Rad (Hercules, CA, USA). Polyvinylidene fluoride (PVDF) membrane (Immobilon-P) was purchased from Millipore (Bedford, MA, USA). Mouse monoclonal anti-caspase 3, Bcl-2, cyclin $\mathrm{A}$, cyclin D1, and cyclin B1 antibodies were obtained from Zymed (San Francisco, CA, USA). Goat polyclonal antipoly [ADP-ribose] polymerase (PARP) antibody, goat antirabbit, and anti-mouse and rabbit anti-goat secondary antibodies conjugated with peroxidase were obtained from $\mathrm{R} \& \mathrm{D}$ Systems (Minneapolis, MN, USA). X-ray film was purchased from Fuji (Tokyo, Japan).

2.2. Cell Lines. Human CRC cell lines Colo320DM and SW480 were obtained from the Bioresource Collection and Research Center in Taiwan. The culture conditions were as recommended by the Bioresource Collection and Research Center. All experiments were carried out on cell lines passaged between 5 and 20 times. Fresh Litchi fruit were purchased from a certificated Litchi farm (Tainan, Taiwan).

2.3. Litchi Seed Extraction. Litchi fruit was washed and peeled, and then the seeds were dried in a $70^{\circ} \mathrm{C}$ oven for at least $48 \mathrm{~h}$. The dried seeds were then ground using a stainlesssteel grinder (RT-02, Rong Tsong Iron Factory Incorporation, Taiwan). The powder was sealed and stored at $-20^{\circ} \mathrm{C}$, or applied to extraction of the polyphenol compounds. For extraction, Litchi seed powder was refluxed with a 10 times $(\mathrm{v} / \mathrm{w} ; \mathrm{mL} / \mathrm{g})$ ratio of $70 \%$ ethanol solution overnight. The crude extract was filtered through No 1 filter paper, and then centrifuged at $3000 \mathrm{rpm}$ for $30 \mathrm{~min}$. The supernatant was concentrated using a rotary evaporator under reduced pressure in a water bath at $<35^{\circ} \mathrm{C}$ and, then, freeze-dried. The final crude extract was defined as LCSP, in which polyphenol species named total phenols, total flavonoids, and condensed tannins were measured by colorimetry methods as previously described [16, 17]. Briefly, the amount of total phenolics in LCSP, estimated by the Folin-Ciocalteu method, was performed by mixing the samples $(0.25 \mathrm{~mL})$ with $3.5 \mathrm{~mL}$ of distilled water in screw-capped test tubes followed by addition of $0.5 \mathrm{~mL}$ of Folin-Ciocalteu solution. After $3 \mathrm{~min}$, $1 \mathrm{~mL}$ of sodium carbonate $(20 \%)$ was added, and the test tubes were properly shaken before they were incubated in a boiling water bath for $1 \mathrm{~min}$. The tubes were then allowed to cool in darkness. A blue coloration was developed, and the absorbance was read at $685 \mathrm{~nm}$. Results were expressed in $\mathrm{mg}$ of gallic acid equivalent/g dry mass LCSP. The total flavonoid content of LCSP, measured by the $\mathrm{AlCl}_{3}$ method, was assessed by mixing aliquots of $1.5 \mathrm{~mL}$ of LCSP with equal volumes of a solution of $2 \% \mathrm{AlCl}_{3} \cdot 6 \mathrm{H}_{2} \mathrm{O}(2 \mathrm{~g}$ in $100 \mathrm{~mL}$ methanol). The mixture was vigorously shaken, and absorbance was read at $367.5 \mathrm{~nm}$ after $10 \mathrm{~min}$ of incubation. Flavonoid contents were expressed in $\mathrm{mg}$ catechin equivalent/g dry weight of LCSP. Condensed tannins of LCSP, determined by the vanillin method, was performed by mixing an aliquot of LCSP with a final volume of $5 \mathrm{~mL}$ of vanillin reagent $(0.5 \%$ vanillin in glacial acetic acid containing $4 \% \mathrm{HCl}$ ). The formed pink chromogen was read at $510 \mathrm{~nm}$. The concentration of condensed tannins was expressed as catechin equivalent of LCSP.

2.4. Cell Proliferation Assay. SW 480 and Colo320DM cells were plated at 100,000 cells in $60 \mathrm{~mm}$ tissue culture dishes. After $18 \mathrm{~h}$ of culture, cells were treated with $\operatorname{LCSP}(0,12.5$, $25,50,100$, or $150 \mu \mathrm{g} / \mathrm{mL}$ ). At $24 \mathrm{~h}$, cells were collected by trypsinization, stained with trypan blue, and the suspensions were counted in duplicate using a hemocytometer. Data are the averages of three independent experiments.

2.5. Cell Cycle Analysis. The treated cells were harvested and washed with phosphate-buffered saline and fixed in $70 \%$ ethanol at $-20^{\circ} \mathrm{C}$ for at least $30 \mathrm{~min}$. The fixed cells were then reconstituted in phosphate-buffered saline and stained with propidium iodide solution (containing $20 \mu \mathrm{g} / \mathrm{mL}$ propidium iodide and $10 \mu \mathrm{g} / \mathrm{mL}$ RNase A) at $37^{\circ} \mathrm{C}$ in the dark for $30 \mathrm{~min}$. The stained cells were examined by flow cytometry using FL-2A to score the DNA content of the cells. The percentages of cells in the G1, S, and G2/M cell-cycle phases were determined using Modfit software (Verity Software House, Topsham, ME, USA).

2.6. Apoptosis Analysis. Measurement of apoptosis was carried out using annexin $\mathrm{V}$ to label phosphatidylserine on the surface of apoptotic cells [18]. Briefly, the harvested cells were suspended in binding buffer (10 mM HEPES, pH 7.4, $140 \mathrm{mM} \mathrm{NaCl}$, and $2.5 \mathrm{mM} \mathrm{CaCl}_{2}$ ) and then stained with annexin $\mathrm{V}$ conjugated with fluorescein isothiocyanate (FITC) at room temperature in the dark for $30 \mathrm{~min}$. The cells were analyzed by flow cytometry to measure the fluorescence intensity using the FL-1H parameter to detect FITC. Untreated cells served as the negative control.

2.7. Immunoblotting. CRC cells were washed twice with ice-cold phosphate-buffered saline and lysed in $0.5 \mathrm{~mL}$ of homogenization buffer $(10 \mathrm{mM}$ Tris- $\mathrm{HCl}$ at $\mathrm{pH} 7.4,2 \mathrm{mM}$ EDTA, $1 \mathrm{mM}$ EGTA, $50 \mathrm{mM} \mathrm{NaCl}, 1 \%$ Triton X-100, $50 \mathrm{mM}$ $\mathrm{NaF}, 20 \mathrm{mM}$ sodium pyrophosphate, $1 \mathrm{mM}$ sodium orthovanadate, and $1: 100 \mathrm{v}: \mathrm{v}$ proteinase inhibitor cocktail) at 
$4^{\circ} \mathrm{C}$ for $30 \mathrm{~min}$. Cell lysates were then ultracentrifuged at $100,000 \mathrm{~g}$ for $30 \mathrm{~min}$ at $4^{\circ} \mathrm{C}$ and the supernatants were used as the cell extracts. The protein concentration of the cell extract was determined by BCA protein assay and adjusted to $2 \mathrm{mg} / \mathrm{mL}$ with homogenization buffer. For immunoblot analysis, the cell extract was subjected to $12 \%$ SDS-PAGE and the resolved bands were electrotransferred to PVDF membranes using semidry blot apparatus (Bio-Rad) at $3 \mathrm{~mA}$

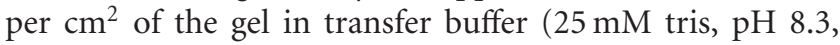
$192 \mathrm{mM}$ glycine, and 20\% methanol) at room temperature for $30 \mathrm{~min}$. The free protein binding sites on the PVDF membrane were blocked by incubation with $5 \%$ nonfat milk in TTBS buffer $(20 \mathrm{mM}$ tris at $\mathrm{pH} 7.4,0.15 \mathrm{M} \mathrm{NaCl}$, and $0.2 \%$ Tween-20) at $25^{\circ} \mathrm{C}$ for $2 \mathrm{~h}$. The membrane was immunoblotted with $0.1 \mu \mathrm{g} / \mathrm{mL}$ primary antibody in TTBS buffer containing $3 \%$ nonfat milk at $4^{\circ} \mathrm{C}$ overnight and then with secondary antibody conjugated with peroxidase $(1: 1000)$ at $25^{\circ} \mathrm{C}$ for $1 \mathrm{~h}$. Immunoblots were developed using an enhanced chemiluminescence system [18]. The luminescence was visualized on X-ray film.

2.8. Statistical Analysis. All data are expressed as mean values \pm standard deviation (SD) unless stated otherwise. Differences between groups were calculated using Student's unpaired $t$-tests. The dose-dependent effect was calculated using simple linear regression. $P<0.05$ was regarded as statistically significant. All statistical analyses were performed using SPSS version 12.0 (SPSS, Inc., Chicago, IL, USA).

\section{Results}

3.1. Analysis of Phytochemicals in LCSP. The phytochemicals (polyphenols, flavonoids, condensed tannins) in the LCSP used here were determined by colorimetry. The content of total phenol in LCSP was $342.5 \pm 4.3 \mathrm{mg}$ gallic acid equivalent/g of dry mass LCSP. The amounts of flavonoids and condensed tannins in LCSP were $195.3 \pm 6.7$ and $230.2 \pm$ $3.6 \mathrm{mg}$ catechin equivalent/g of dry mass LCSP, respectively. These results indicate that the LCSP used here was a polyphenol-rich substance with flavonoids and condensed tannins as dominant compounds.

3.2. Inhibition of CRC Cell Growth. The effect of LCSP on the cell survival of two CRC cell lines was shown in Figure 1. Surviving cells decreased in a dose-dependent manner $(P<$ 0.05 ) after 24 hours of treatment of Colo320DM and SW 480. SW480 cells were more sensitive to LCSP, with a greater than $60 \%$ inhibition at a concentration of $25 \mu \mathrm{g} / \mathrm{mL}$. Colo320DM showed a similar sensitivity at a concentration of $50 \mu \mathrm{g} / \mathrm{mL}$.

3.3. LCSP Blocked CRC Cells during G2/M Phase. To determine the cellular mechanism of growth inhibition of LCSP in CRC cells, we investigated cell cycle progression after LCSP treatment. As shown in Figure 2(a), the distribution of all three phases of Colo320DM did not change significantly at LCSP concentrations lower than $50 \mu \mathrm{g} / \mathrm{mL}$. However, when the LCSP concentration was increased to $100 \mu \mathrm{g} / \mathrm{mL}$, the

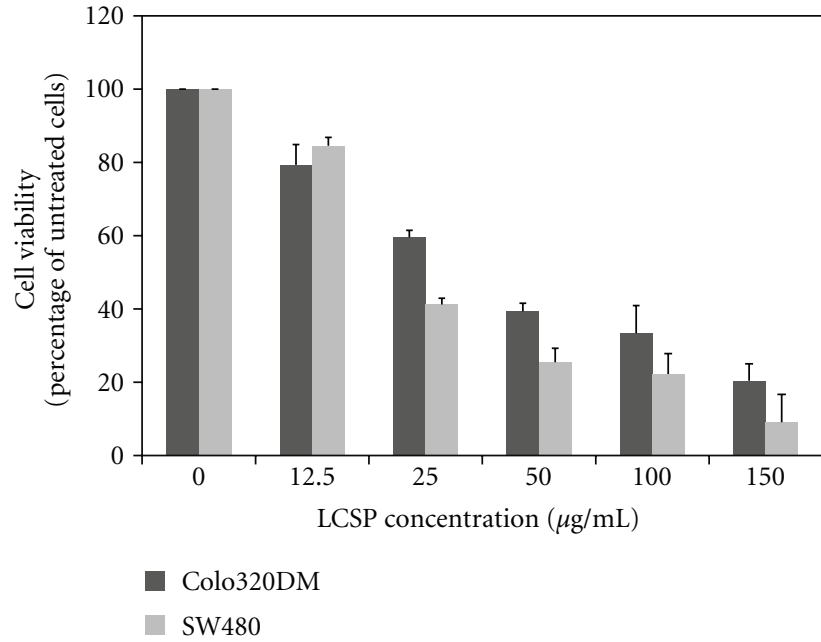

FIgure 1: The dose-dependent response of CRC cells to LCSP. Colo320DM and SW480 cells were treated with increasing concentrations of LCSP as indicated and then incubated at $37^{\circ} \mathrm{C}$ for $24 \mathrm{~h}$. Viable cells were trypsinized, stained with trypan blue, and counted under a microscope. Cell viability was expressed as a percentage of untreated cells. Data are the average of three independent experiments and are expressed as means $\pm \mathrm{SD}$.

number of G2/M phase cells increased significantly, whereas the number of G0/G1 phase cells decreased. A similar effect on the cell cycle distribution was found for LCSP-treated SW480 cells when the concentration of LCSP was $100 \mu \mathrm{g} / \mathrm{mL}$ (Figure 2(b)).

3.4. Expression Levels of Cyclin D1, A, and B in LCSPTreated CRC. To confirm the cell cycle distribution change after LCSP treatment, the protein levels of cyclin D1, A, and $\mathrm{B} 1$ were determined by immunoblotting. As shown in Figure 3, the cyclin D1 and cyclin B1 levels in LCSP-treated Colo320DM cells was decreased gradually but still expressed at even LCSP concentration greater than $100 \mu \mathrm{g} / \mathrm{mL}$. The level of cyclin A was significantly decreased at LCSP concentrations greater than $100 \mu \mathrm{g} / \mathrm{mL}$. The changes in the levels of these cyclins were closely associated with G2/M phase arrest of the cell cycle. Differing from Colo320DM, LCSP treatment of SW480 cells at 100 to $150 \mu \mathrm{g} / \mathrm{mL}$ decreased the levels of cyclin D1, A, and B1. The changes of cyclin levels in SW480 were also correlated with the cell cycle arrest at G2/M, as shown in Figure 2(b). Levels of $\beta$-actin served as an internal control.

3.5. LCSP-Induced Apoptotic Death of CRC Cells. Phosphatidylserine translocation was assessed to determine apoptosis of LCSP-treated CRC cells by staining with FITCconjugated annexin V. Annexin V positive cells increased in a dose-dependent manner in Colo320DM and SW480 cells (Figure 4). Both of these two cell lines showed significantly more apoptotic cells at $>12.5 \mu \mathrm{g} / \mathrm{mL}$ LCSP for SW480 cells and $>25 \mu \mathrm{g} / \mathrm{mL}$ LCSP for Colo320DM cells. 


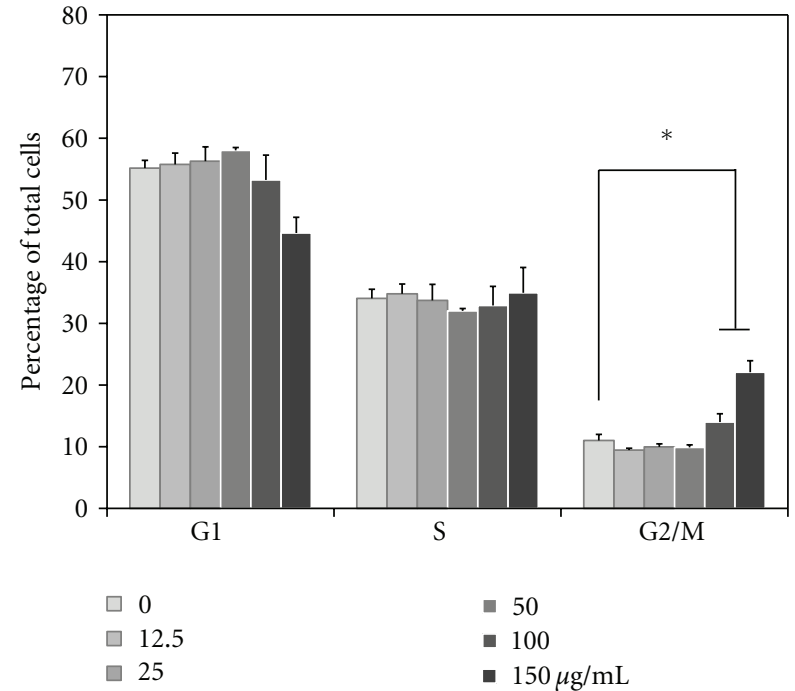

(a)

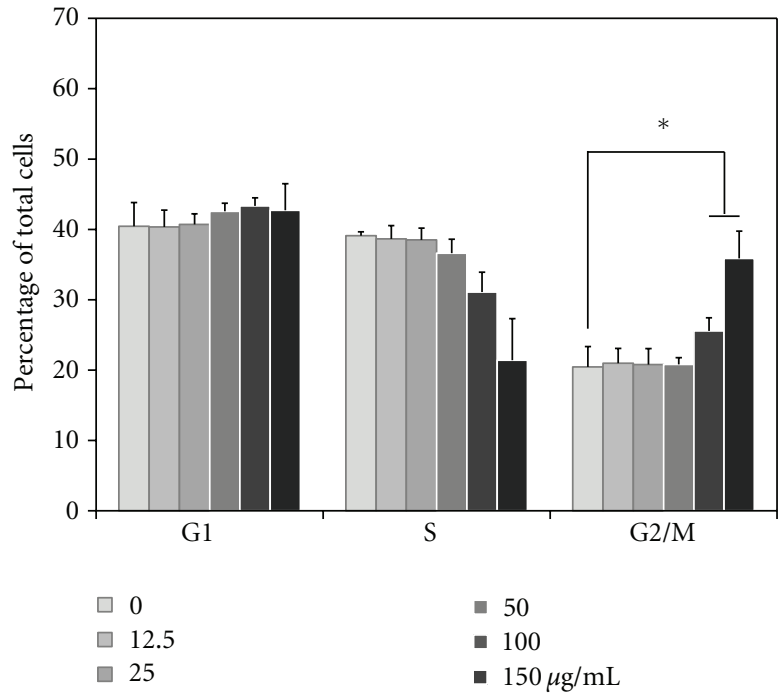

(b)

FIGURe 2: Cell cycle analysis of LCSP-treated CRC cells. Cells were treated with increasing concentrations of LCSP as indicated and then incubated at $37^{\circ} \mathrm{C}$ for $24 \mathrm{~h}$. Cells were harvested and fixed in $70 \%$ alcohol and then stained with propidium. Stained cells were analyzed using a flow cytometer and the distributions in each cell cycle phase of Colo320DM (a) and SW480 (b) were determined using Modfit software. Data are expressed as a percentage of total cells, represent the averages of three independent experiments, and are expressed as the mean \pm SD. ${ }^{*}$ Represents a significant difference $(P<0.05)$.

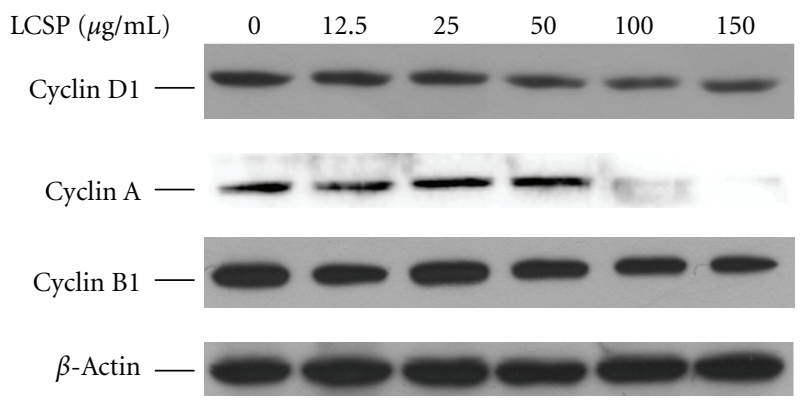

(a)

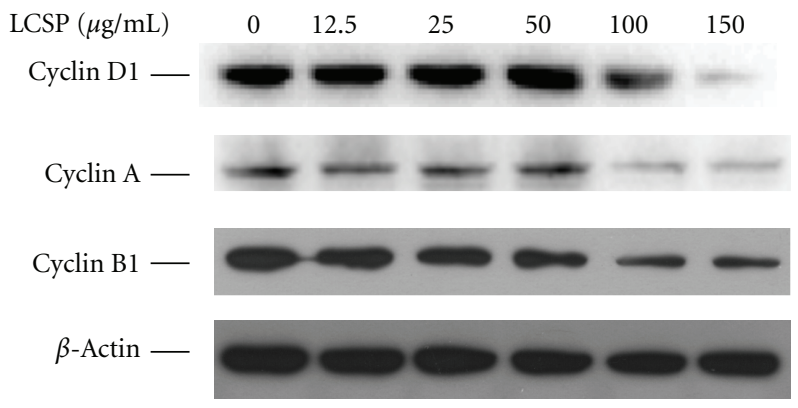

(b)

FIGURE 3: Immunoblots of cell cycle-controlling proteins in LCSP-treated CRC cells. Cells were treated with increasing concentrations of LCSP as indicated and then incubated at $37^{\circ} \mathrm{C}$ for $24 \mathrm{~h}$. Cell protein lysates from Colo320DM (a) and SW480 (b) cells were separated by SDS-PAGE, transferred to PVDF membranes, and immunoblotted to show cyclin D1, cyclin A, and cyclin B1 levels, and the beta-actin level as a loading control.

3.6. The Protein Levels of Bcl-2, Caspase-3, and PARP in LCSP-Treated CRC Cells. The procaspase 3 level in LCSPtreated Colo320DM and SW480 cells gradually decreased (Figure 5(a)), The cleaved PARP level in these two cell lines increased at $12.5 \mu \mathrm{g} / \mathrm{mL}$ for SW480 and at $25 \mu \mathrm{g} / \mathrm{mL}$ for Colo 320DM, which was correlated with cellular apoptosis (Figure 4).

3.7. Bax:Bcl-2 Ratio in LCSP-Treated CRC Cells. The Bax: $\mathrm{Bcl}-2$ ratio is important in apoptosis. Although the Bcl-2 protein expression was not changed in both CRC cells under high-dosage treatment $(150 \mu \mathrm{g} / \mathrm{mL})$ compared with untreated cells, Bax protein gradually increased in LCSPtreated CRC cells (Figures 5(a) and 5(b)). The change in the
Bax: Bcl-2 ratio under LCSP treatment was increased at $>12.5 \mu \mathrm{g} / \mathrm{mL}$ in SW480 cells and at $>25 \mu \mathrm{g} / \mathrm{mL}$ Colo 320DM (Figure 5(c)). The Bax: Bcl-2 ratio was closely correlated with the apoptosis induction in both LCSP-treated CRC cells.

\section{Discussion}

This study found that the response to LCSP treatment was similar in the two CRC cell lines, SW480 and Colo320DM. Proliferation of SW480 and Colo320DM was inhibited by LCSP in a dose-dependent manner, although the sensitivity of SW480 to LCSP was slightly higher than Colo 320DM. To the best of our knowledge, this is the first report to show that LCSP can inhibit proliferation of CRC cells. Previous studies have revealed that Litchi seeds are mainly composed of 


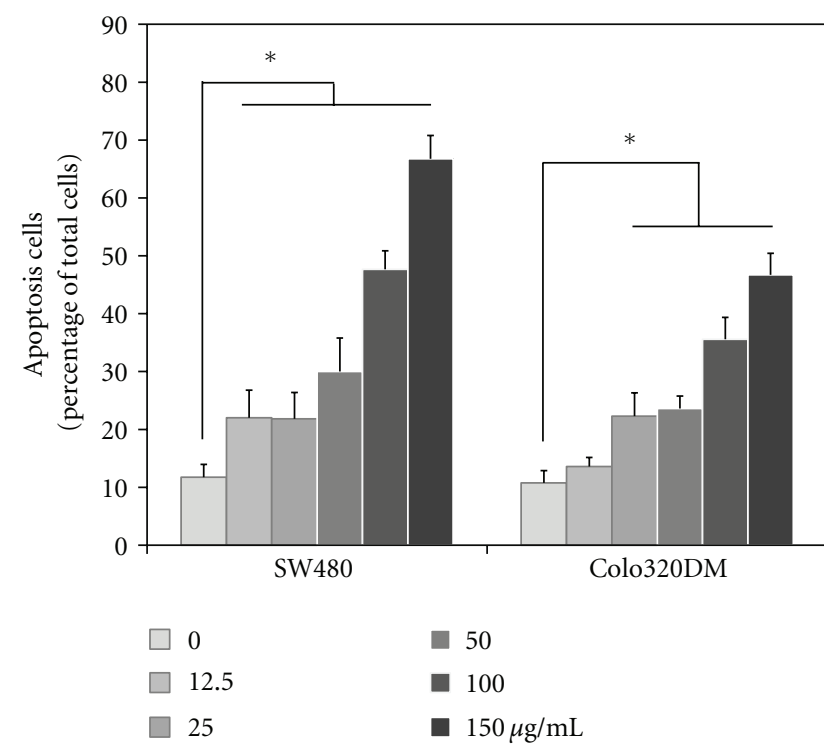

Figure 4: Detection of apoptotic induction by LCSP. Cells were treated with increasing concentrations ofLCSP as indicated, then incubated at $37^{\circ} \mathrm{C}$ for $24 \mathrm{~h}$. The treated cells were then suspended and stained with annexin V conjugated with FITC. Ten thousand cells were analyzed by flow cytometry. Data are the averages of three independent experiments and are expressed as the mean $\pm \mathrm{SD}$. * Represents a significant difference $(P<0.05)$.

lichitanin A and proanthocyanidin [13]. The major structure of lichitanin is catechin and epicatechin. Purified compounds of these two substances inhibited cancer cell proliferation in vitro, suggesting the potential role of Litchi seed extract on cancer prevention and treatment [19]. Plant extracts with high levels of flavonoids and proanthocyanidins have also been studied and are regarded as nutrients with cancerpreventive characteristics $[8,20]$. The effect of inhibition of CRC cells by LCSP is same as that of purified compounds and polyphenolics from other natural products $[17,18,21]$. In the current study, we also demonstrated that Litchi seed ethanol extract indeed composed of significant amounts of flavonoids and could inhibit proliferation of CRC cells.

The inhibitory effect of LCSP on the proliferation of CRC cells may involve with two cellular mechanisms, cell cycle arrest and induction of apoptosis. Our investigation of the cell cycle distribution of LCSP-treated CRC cells revealed that the cell cycle was arrested in the G2/M phase when $>100 \mu \mathrm{g} / \mathrm{mL}$ LCSP was applied to the cells. The cell cycle is controlled by a group of regulatory proteins named cyclins. Cyclin D1 is an important regulator of G1 phase progression in many different cell types including CRC cells [22]. In this study, LCSP treatment decreased the level of cyclin D1 gradually in Colo 320DM and at a dosage greater than $100 \mu \mathrm{g} / \mathrm{mL}$ in SW480 cells, which is correlated with the cell cycle analysis showing G2/M phase arrest. In addition, cyclin A is synthesized during the S phase. Disruption of cyclin A function can inhibit chromosomal DNA replication [23]. Cyclin B1 is made in the G2 and M phases of the cell cycle. A decrease in cyclin B1 blocks the cell cycle from progressing into mitosis [24]. Together with alteration of cyclin D1, these findings suggest that the effect of LCSP on the cell division cycle is mainly due to disturb G2/M progression. Previous studies have confirmed that increases in CRC cells in the $S$ phase are associated with perturbation of the G1/S or S/G2 phase transition following treatment with grape seed, Longon seed, or Longon flower extract [17, 18, 25]. In this study, CRC cells exhibited significant increases in the number of G2/M phase cells following treatment with $>100 \mu \mathrm{g} / \mathrm{mL}$ of LCSP, which differed from previous reports. These findings suggested that the anti-proliferative effect induced by polyphenols from naturally occurring products could occur through a different cell cycle controlling mechanism. The different composition of the polyphenols in each natural product might induce different expressions of cyclin proteins to control the cell cycle in CRC cells. Whether the alteration of cyclin D1 and A levels by LCSP treatment is the only molecular mechanism responsible for the perturbation of the M to G1 phase of the cell cycle in CRC cells needs further investigation.

Induction of apoptosis is another possible mechanism by which the antiproliferative activity of LCSP in CRC cells may be exerted. In current study, we demonstrated that LCSP-treated CRC cells express an apoptotic reaction. The evidence included annexin $\mathrm{V}$ analysis and activation of the caspase pathway in the treated CRC cells. The induction of expression of caspase 3 is a crucial step in curcumin- and gypenoside-induced apoptosis in CRC cells [26-28]. Previous studies have also suggested that caspase 3 is activated during polyphenolic-induced apoptosis in CRC cells [17, $18,21]$. In the present study, LCSP treatment increased the protein level of the active form of caspase 3 in CRC cells, further indicating that LCSP-induced apoptosis is mediated by caspase 3 activation. The subsequent increase in cleavage of caspase 3 substrate PARP in LCSP-treated CRC cells confirmed the activation of caspase 3. LCSP-induced apoptosis may operate through the Bcl-2 family of proteins. Bcl-2 proteins are important mediators of apoptosis in CRC cells [29, 30]. Some family members promote apoptosis (e.g., Bax and Bad), while others inhibit it (e.g., Bcl-2 and Bcl-x) [31, 32]. These proteins form multimers, which act as pores in cell membranes, controlling the flux of molecules between cellular compartments. Recent reports have indicated that the ratio of $\mathrm{Bax}: \mathrm{Bcl}-2$ proteins is the determining factor in transmitting the apoptotic signal [33-36]. Previous reports have shown that grape seed extract inhibits the expression of Bcl-2 protein in breast and skin carcinoma cells $[37,38]$. Additionally, in our previous reports, we also confirmed that longan seed extract increases the Bax:Bcl-2 ratio in CRC cells [18]. Although LCSP influenced different changes in the expression of Bax and Bcl-2 in SW480 and Colo320DM in our study, the Bax:Bcl-2 ratio increased significantly and was correlated with the dosage of LCSP in SW480 CRC cells. These results underline the importance of the Bax:Bcl-2 ratio in cancer cell life and death $[33,34]$. Taken together, the above results demonstrated that LCSP-induced apoptosis in CRC cells was mediated by an increasing Bax : Bcl-2 ratio.

In conclusion, this study demonstrated that LCSP treatment inhibited cell proliferation in Colo320DM and SW480. 


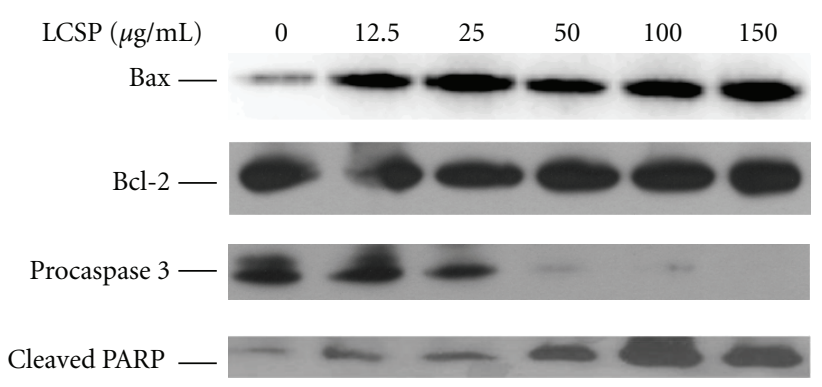

(a)

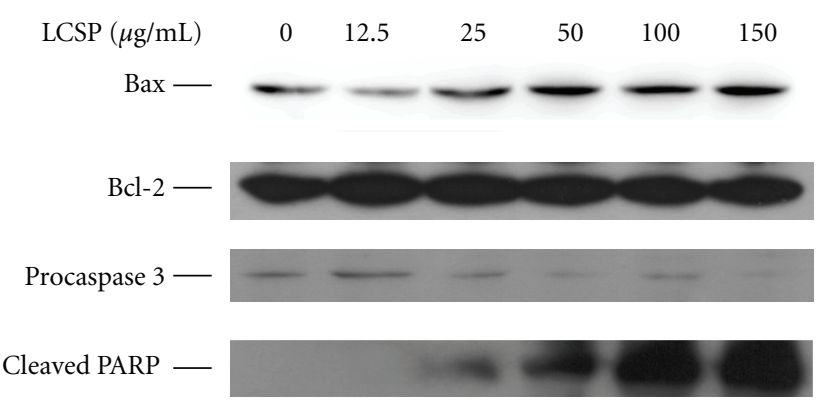

(b)

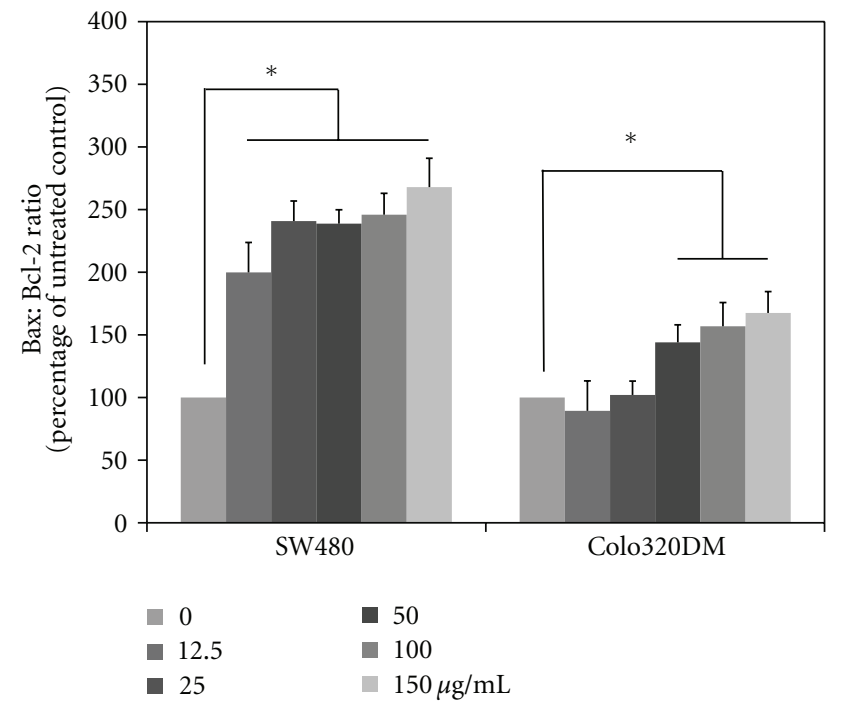

(c)

FIGURE 5: Immunoblots of apoptosis-controlling proteins in LCSP-treated colorectal carcinoma cells. The cell lysates from LCSP-treated SW480 (a) and Colo320DM (b) were separated by SDS-PAGE, transferred to PVDF membranes, and immunoblotted to show the levels of Bax, Bcl-2, procaspase 3 and cleavage-PARP. The protein levels of Bax and Bcl-2 were quantified using Image software according to the density of each band on the immunoblotting image, normalized to the reference band ( $\beta$-actin), and presented as the fold of the untreated control. (c) The data reported are the averages of three independent experiments and are expressed as means \pm SD. * Represents a significant difference $(P<0.05)$.

LCSP inhibited CRC cells mainly through G2/M phase arrest of the cell cycle through decreased levels of cyclin D1, A, and B1. LCSP also operate through apoptosis by altering the Bax:Bcl-2 ratio and activating caspase 3 in both CRC cells. However, upstream factors mediating LCSP induction of G2/M phase arrest and apoptosis need further investigation. We found that LCSP treatment could inhibit proliferation and induce apoptosis in CRC cell lines, suggesting its potential as a novel chemoprevention agent for CRC in the future.

\section{Abbreviations}

LCSP: litchi seed polyphenols

CRC: colorectal cancer

BCA: bicinchoninic acid

PARP: $\quad$ poly [ADP-ribose] polymerase

PVDF: $\quad$ polyvinylidene fluoride

SDS-PAGE: sodium dodecylsulfate polyacrylamide gel electrophoresis.

\section{References}

[1] J. H. Ju, S. C. Chang, H. S. Wang et al., "Changes in disease pattern and treatment outcome of colorectal cancer: a review of 5,474 cases in 20 years," International Journal of Colorectal Disease, vol. 22, no. 8, pp. 855-862, 2007.

[2] Taiwan Department of Health, Executive Yuan. Health and Vital Statistics, Cancer Registry Annual Report in Taiwan Area, 2009, http://www.bhp.doh.gov.tw/BHPnet/Portal/.

[3] E. Gontier, N. Boussouel, C. Terrasse et al., "Litchi chinensis fatty acid diversity: occurrence of the unusual cyclopropanoic fatty acids," Biochemical Society Transactions, vol. 28, no. 6, pp. 578-580, 2000.

[4] Y. B. Chen, K. S. Wu, Y. Gu, and J. Z. Chen, "Research progress in the chemical constituents and pharmacological effects of lychee seeds," Chinese Journal of Infection, vol. 14, pp. 97-98, 2007.

[5] A. H. Xiong, W. J. Shen, L. Y. Xiao, and J. H. Lv, "Effect of Semen Litchi containing serum on proliferation and apoptosis of HepG2 cells," Zhongyaocai, vol. 31, no. 10, pp. 1533-1536, 2008. 
[6] L. Y. Xiao, D. Zhang, Z. M. Feng, Y. W. Chen, H. Zhang, and P. Y. Lin, "Studies on the antitumor effect of lychee seeds in mice," Journal of Chinese Medicine Materials, vol. 27, pp. 517518, 2004.

[7] J. Li and Y. Jiang, "Litchi flavonoids: isolation, identification and biological activity," Molecules, vol. 12, no. 4, pp. 745-758, 2007.

[8] T. Ariga, "The antioxidative function, preventive action on disease and utilization of proanthocyanidins," BioFactors, vol. 21, no. 1-4, pp. 197-201, 2004.

[9] M. Kaur, B. Velmurugan, S. Rajamanickam, R. Agarwal, and C. Agarwal, "Gallic acid, an active constituent of grape seed extract, exhibits anti-proliferative, pro-apoptotic and antitumorigenic effects against prostate carcinoma xenograft growth in nude mice," Pharmaceutical Research, vol. 26, no. 9, pp. 2133-2140, 2009.

[10] X. Wang, S. Yuan, J. Wang et al., "Anticancer activity of litchi fruit pericarp extract against human breast cancer in vitro and in vivo," Toxicology and Applied Pharmacology, vol. 215, no. 2, pp. 168-178, 2006.

[11] X. Wang, Y. Wei, S. Yuan, G. Liu, Y. L. J. Zhang, and W. Wang, "Potential anticancer activity of litchi fruit pericarp extract against hepatocellular carcinoma in vitro and in vivo," Cancer Letters, vol. 239, no. 1, pp. 144-150, 2006.

[12] C. J. Huang and M. C. Wu, "Differential effects of foods traditionally regarded as "heating" and "cooling" on prostaglandin $\mathrm{E}(2)$ production by a macrophage cell line," Journal of Biomedical Science, vol. 9, no. 6, pp. 596-606, 2002.

[13] X. Xu, H. Xie, Y. Wang, and X. Wei, "A-type proanthocyanidins from lychee seeds and their antioxidant and antiviral activities," Journal of Agricultural and Food Chemistry, vol. 58, no. 22, pp. 11667-11672, 2010.

[14] X. Xu, H. Xie, L. Xu, and X. Wei, "A novel cyclopropyl-containing fatty acid glucoside from the seeds of Litchi chinensis," Fitoterapia, vol. 82, no. 3, pp. 485-488, 2011.

[15] X. Xu, H. Xie, J. Hao, Y. Jiang, and X. Wei, "Flavonoid glycosides from the seeds of litchi chinensis," Journal of Agricultural and Food Chemistry, vol. 59, no. 4, pp. 1205-1209, 2011.

[16] S. C. Ho, L. S. Hwang, Y. J. Shen, and C. C. Lin, "Suppressive effect of a proanthocyanidin-rich extract from longan (Dimocarpus longan Lour.) flowers on nitric oxide production in lpsstimulated macrophage cells," Journal of Agricultural and Food Chemistry, vol. 55, no. 26, pp. 10664-10670, 2007.

[17] C. P. Hsu, Y. H. Lin, S. P. Zhou, Y. C. Chung, C. C. Lin, and S. C. Wang, "Longan flower extract inhibits the growth of colorectal carcinoma," Nutrition and Cancer, vol. 62, no. 2, pp. 229-236, 2010.

[18] Y. C. Chung, C. C. Lin, C. C. Chou, and C. P. Hsu, "The effect of Longan seed polyphenols on colorectal carcinoma cells," European Journal of Clinical Investigation, vol. 40, no. 8, pp. 713-721, 2010.

[19] N. Kumar, D. Shibata, J. Helm, D. Coppola, and M. Malafa, "Green tea polyphenols in the prevention of colon cancer," Frontiers in Bioscience, vol. 12, no. 6, pp. 2309-2315, 2007.

[20] D. Bagchi, M. Bagchi, S. J. Stohs et al., "Free radicals and grape seed proanthocyanidin extract: importance in human health and disease prevention," Toxicology, vol. 148, no. 2-3, pp. 187197, 2000.

[21] C. P. Hsu, Y. H. Lin, C. C. Chou et al., "Mechanisms of grape seed procyanidin-induced apoptosis in colorectal carcinoma cells," Anticancer Research, vol. 29, no. 1, pp. 283-289, 2009.

[22] J. P. Alao, "The regulation of cyclin D1 degradation: roles in cancer development and the potential for therapeutic invention," Molecular Cancer, vol. 6, article 24, 2007.
[23] J. Pines and T. Hunter, "p34(cdc2): the S and M kinase?" The New Biologist, vol. 2, no. 5, pp. 389-401, 1990.

[24] A. Lindqvist, V. Rodríguez-Bravo, and R. H. Medema, "The decision to enter mitosis: feedback and redundancy in the mitotic entry network," Journal of Cell Biology, vol. 185, no. 2, pp. 193-202, 2009.

[25] Y.-C. Chung, C.-C. Huang, C.-H. Chen et al., "Grape-seed procyanidins inhibit the in vitro growth and invasion of pancreatic carcinoma cells," Pancreas, vol. 41, no. 3, pp. 447454, 2012.

[26] C. C. Su, J. G. Lin, T. M. Li et al., "Curcumin-induced apoptosis of human colon cancer colo 205 cells through the production of ROS, $\mathrm{Ca}^{2+}$ and the activation of caspase-3," Anticancer Research, vol. 26, no. 6, pp. 4379-4389, 2006.

[27] J. C. Chen, K. W. Lu, J. H. Lee, C. C. Yeh, and J. G. Chung, "Gypenosides induced apoptosis in human colon cancer cells through the mitochondria-dependent pathways and activation of caspase-3," Anticancer Research, vol. 26, no. 6, pp. 4313-4326, 2006.

[28] A. M. Roy, M. S. Baliga, C. A. Elmets, and S. K. Katiyar, "Grape seed proanthocyanidins induce apoptosis through p53, bax, and caspase 3 pathways," Neoplasia, vol. 7, no. 1, pp. 24-36, 2005.

[29] D. R. Green and J. C. Reed, "Mitochondria and apoptosis," Science, vol. 281, no. 5381, pp. 1309-1312, 1998.

[30] J. C. Reed, "Double identity for proteins of the Bcl-2 family," Nature, vol. 387, no. 6635, pp. 773-776, 1997.

[31] Z. N. Oltvai, C. L. Milliman, and S. J. Korsmeyer, "Bcl-2 heterodimerizes in vivo with a conserved homolog, Bax, that accelerates programed cell death," Cell, vol. 74, no. 4, pp. 609619, 1993.

[32] Q. Zhan, S. Fan, I. Bae et al., "Induction of bax by genotoxic stress in human cells correlates with normal p53 status and apoptosis," Oncogene, vol. 9, no. 12, pp. 3743-3751, 1994.

[33] J. C. Reed, "Balancing cell life and death: bax, apoptosis, and breast cancer," The Journal of Clinical Investigation, vol. 97, no. 11, pp. 2403-2404, 1996.

[34] J. C. Reed, T. Miyashita, S. Takayama et al., "BCL-2 family proteins: regulators of cell death involved in the pathogenesis of cancer and resistance to therapy," Journal of Cellular Biochemistry, vol. 60, no. 1, pp. 23-32, 1996.

[35] C. M. Chresta, J. R. W. Masters, and J. A. Hickman, "Hypersensitivity of human testicular tumors to etoposide-induced apoptosis is associated with functional p53 and a high Bax: Bcl-2 ratio," Cancer Research, vol. 56, no. 8, pp. 18341841, 1996.

[36] S. K. Mantena, M. S. Baliga, and S. K. Katiyar, "Grape seed proanthocyanidins induce apoptosis and inhibit metastasis of highly metastatic breast carcinoma cells," Carcinogenesis, vol. 27, no. 8, pp. 1682-1691, 2006.

[37] S. M. Meeran and S. K. Katiyar, "Grape seed proanthocyanidins promote apoptosis in human epidermoid carcinoma A431 cells through alterations in Cdki-Cdk-cyclin cascade, and caspase- 3 activation via loss of mitochondrial membrane potential," Experimental Dermatology, vol. 16, no. 5, pp. 405415, 2007.

[38] E. Bandrés, R. Zárate, N. Ramirez, A. Abajo, N. Bitarte, and J. García-Foncillas, "Pharmacogenomics in colorectal cancer: the first step for individualized-therapy," World Journal of Gastroenterology, vol. 13, no. 44, pp. 5888-5901, 2007. 


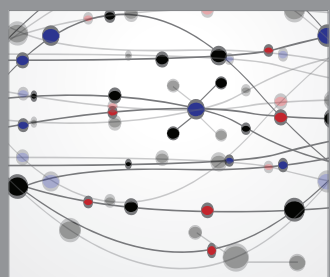

The Scientific World Journal
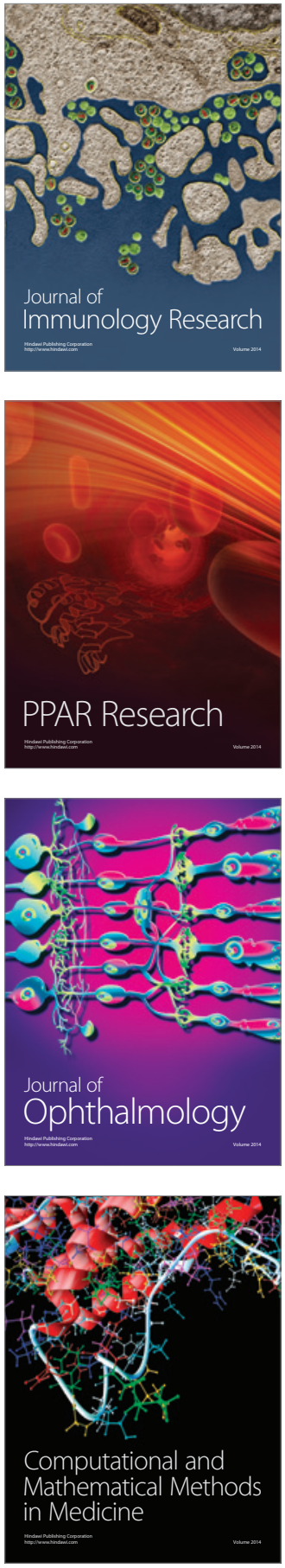

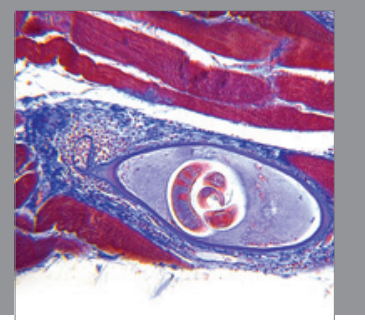

Gastroenterology

Research and Practice
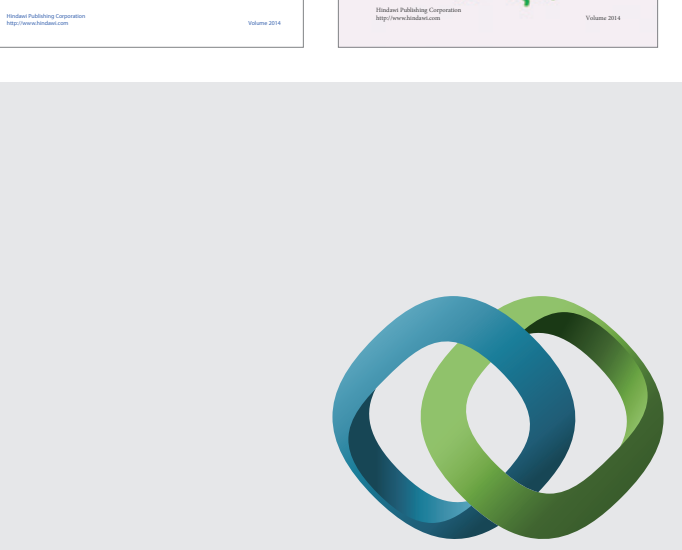

\section{Hindawi}

Submit your manuscripts at

http://www.hindawi.com
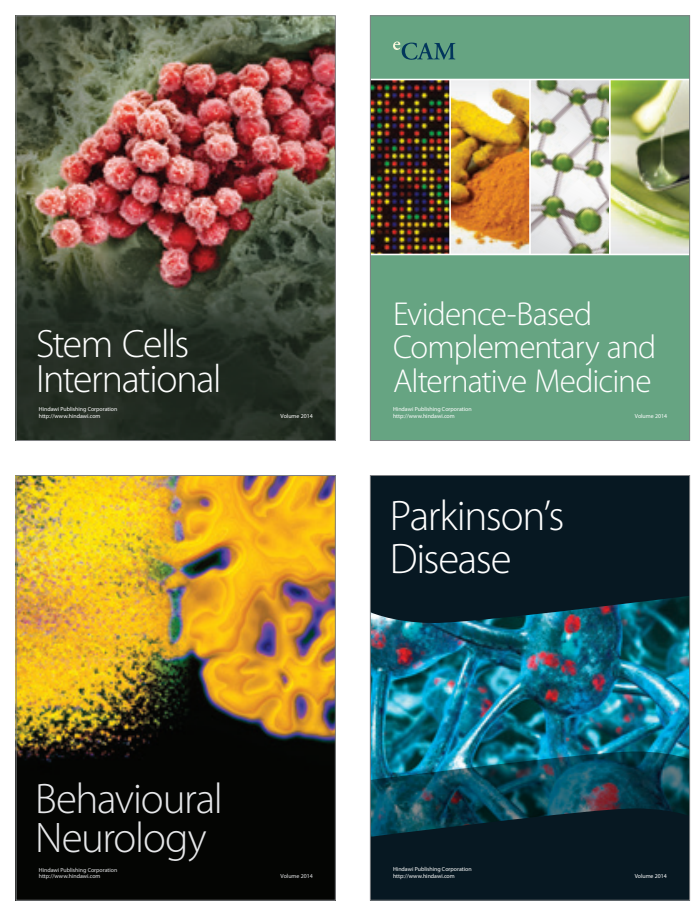

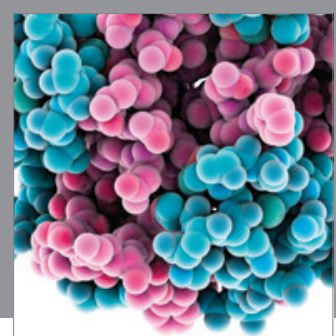

Journal of
Diabetes Research

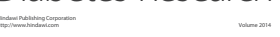

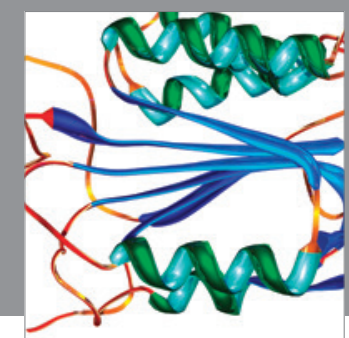

Disease Markers
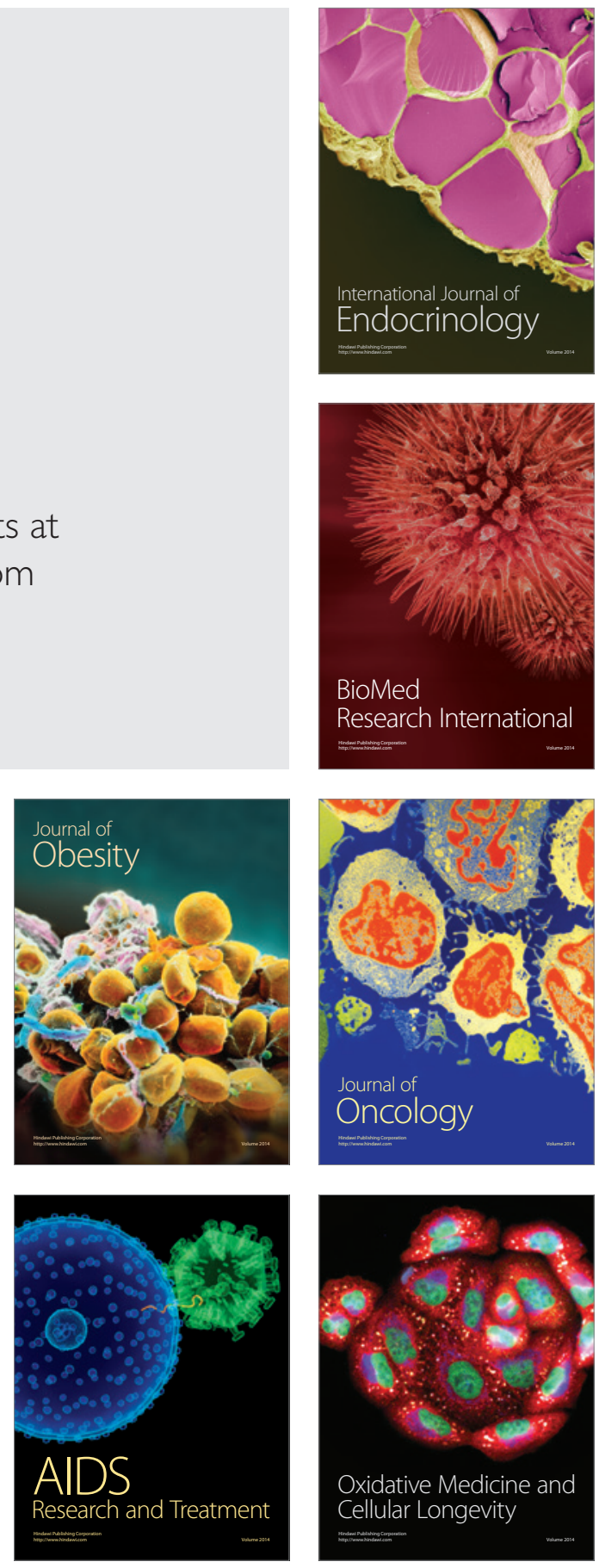